Maria Cristina Franck1,2

Ohttps://orcid.org/0000-0002-2818-0731

Ângela Malysz Sgaravatti

Ohttps://orcid.org/0000-0001-9156-1919

Daniel Scolmeister ${ }^{2}$

Ohttps://orcid.org/0000-0003-3048-0554

Viviane Fassina²

Ohttps://orid.org/0000-0001-7889-0128

Clarissa Cassini Bettoni² $^{2}$

Ohttps://orcid.org/0000-0002-1922-1116

Fernanda Rafaela Jardim²

Ohttps://orcid org/0000-0001-8203-6768

Carla Cafarate Nunes²

ontps://orid.org/0000-0001-6736-830X

Anderson Fraga Morales

Ohttps://orid.org/0000-0002-2245-1772

Renata Pereira Limberger Ohttps://orcid. org/0000-0003-2561-2647

\section{Suicide and associated factors across life span}

\author{
Suicídio e fatores associados ao longo da vida
}

DOl: 10.1590/0047-2085000000254

\begin{abstract}
Objective: To assess the epidemiological and toxicological profile of all suicide victims in 2017 in Rio Grande do Sul, Brazil. Methods: The victims were classified by gender, age, parental absence, city, suicide form, death context, and toxicological results, using the police occurrences and the reports issued by the Instituto-Geral de Perícias do RS. Multiple correspondence analysis and the CochranMantel-Haenszel $X^{2}$ test were used to evaluate associations between the parameters studied. Results: There were 1,284 suicides (11.3 cases/100,000 inhabitants) in RS in 2017, 80\% of which were men and $46 \%$ were young and old. Porto Alegre had the highest number of victims and the region of the Vale do Rio Pardo, the highest rate (20.8 cases/100,000 inhabitants). The hanging was the most used medium and the depression, the most mentioned context in the occurrences. The presence of ethanol was observed in $30 \%$ of the samples analyzed, with an adult male profile associated with the presence of other psychotropic substances, whose class was most frequently detected with anxiolytics. The nitrite was the most detected poison among the samples sent for this purpose. There was an association between parental absence and young people, between suicidal intoxication method and women and among young people and the presence of illicit compounds. Conclusion: Mortality due to suicide continues to increase in RS, which, historically, has the highest Brazilian index. The information obtained in this study supports new research, promoting awareness raising, guidance to health services and the elaboration of more preventive public policies.
\end{abstract}

\section{KEYWORDS}

Suicide, epidemiology, public health, toxicology, multivariate analysis.

\section{RESUMO}

Objetivo: Determinar o perfil epidemiológico e toxicológico de todas as vítimas de suicídio no Rio Grande do Sul em 2017. Métodos: As vítimas foram classificadas por gênero, idade, ausência parental, cidade, forma de suicídio, contexto do óbito e resultados toxicológicos, utilizando as ocorrências policiais e os laudos emitidos pelo Instituto-Geral de Perícias do RS. A análise de correspondência múltipla e o teste Cochran-Mantel-Haenszel $X^{2}$ foram utilizados para avaliar associações entre os parâmetros estudados. Resultados: Foram registrados 1.284 suicídios (11,3 casos/100 mil habitantes) no RS em 2017, sendo $80 \%$ homens e $46 \%$ jovens e idosos. Porto Alegre apresentou o maior número de vítimas e a região do Vale do Rio Pardo, o maior índice (20,8 casos/100 mil habitantes). O enforcamento foi o meio mais empregado e a depressão, o contexto mais citado nas ocorrências. A presença de etanol foi observada em $30 \%$ das amostras analisadas, com perfil masculino adulto associado à presença de outros psicotrópicos, cuja classe mais frequentemente detectada foi a dos ansiolíticos. O nitrito foi o veneno mais detectado entre as amostras encaminhadas para essa finalidade. Houve associação entre a ausência parental e os jovens, entre o método suicida intoxicação e as mulheres e entre os jovens e a presença de compostos ilícitos. Conclusão: A mortalidade por suicídio segue aumentando no RS, que, historicamente, apresenta o maior índice brasileiro. As informações obtidas neste trabalho servem de apoio a novas pesquisas, promovendo ações de conscientização, orientação aos serviços de saúde e na elaboração de mais políticas públicas preventivas.

\section{PALAVRAS-CHAVE}

Suicídio, epidemiologia, saúde pública, toxicologia, análise multivariada.
Received in: Nov/22/2019. Approved in: 14/Dec/2019

1 Universidade Federal do Rio Grande do Sul (UFRGS), Programa de Pós-Graduação em Ciências Farmacêuticas (PPGCF), Porto Alegre, RS, Brasil. 2 Instituto-Geral de Perícias do Rio Grande do Sul (IGP-RS), Porto Alegre, RS, Brasil.

Address for correspondence: Maria Cristina Franck. Universidade Federal do Rio Grande do Sul (UFRGS). Rua Chile, 871/203, Jardim Botânico - $90670-140$ Porto Alegre, RS, Brazil. E-mails: mariacfranck@yahoo.com.br maria-franck@igp.rs.gov.br 


\section{INTRODUCTION}

Suicide is one of the most preventable causes of violent death in modern society, becoming a public health problem? Worldwide, around 800,000 people commit suicide every year ${ }^{2}$, with 65,000 in the Americas region ${ }^{3}$. According to the World Health Organization (WHO), suicide prevention is a global goal, aiming at a $10 \%$ reduction by 20204,5 . In addition, it is also among the United Nations health indicators, whose goal of sustainable development is to reduce, by 2030, premature mortality from non-communicable diseases by preventing, treating and promoting mental health and well-being ${ }^{5}$.

In Brazil there were 8,000 cases of suicide in 2004 and more than 10,000 in 2014,7. While the Brazilian population increased by $17.8 \%$ between 1998 and 2008, the number of deaths from suicide increased by $33.5 \%{ }^{8}$. The average case rate per 100,000 inhabitants/year in 2016 in Brazil was 6.19 and this national average hides important regional variations ${ }^{8,9}$, indicating the need for local monitoring and control processes aligned with governmental preventive measures ${ }^{5}$.

The state of Rio Grande do Sul (RS) has, historically, had the highest Brazilian suicide rate ${ }^{10-12}$, with an annual average (2016) of 11.0 cases per 100,000 inhabitants ${ }^{10}$. In this sense, the objective of this study was to characterize the epidemiological and toxicological profile of all RS suicide victims in 2017, in order to support the elaboration of preventive strategies directed to the regions and the population most vulnerable to this psychosocial problem.

\section{METHODS}

The occurrences of the Polícia Civil do RS, the reports of the Department of Forensic Medicine and the examinations performed by the Department of Laboratory Forensics related to all deaths by suicide, submitted to necropsy by the Instituto-Geral de Perícias do RS, from January 1st to December 31, 2017, were included in this work.

Victims were classified by gender, age, parental absence in the birth certificate, city, region ${ }^{13}$, macroregion ${ }^{14}$, suicide form, death context, and toxicological findings. Alcoholic dosages were performed on whole blood samples and qualitative analyzes of psychotropics and poisons on urine, vitreous humor, stomach and contents, liver and/or brain.

The study was retrospective and descriptive, and suicide rates for every 100,000 inhabitants were calculated from population data estimated for 2017 by the Instituto Brasileiro de Geografia e Estatística ${ }^{15}$.

Multiple correspondence analysis, Cochran-MantelHaenszel $X^{2}$ with continuity correction $(\mathrm{CMH})$ and Breslow-Day tests were performed using the free software
$R^{\circ}$ version 3.5.1, with a significance level of $0.05 \%$, excluding observations with missing data.

The study project was approved by the Research Ethics Committee of the Federal University of Rio Grande do Sul, under number 2532550 .

\section{RESULTS}

A total of 1,284 deaths from suicide in RS were recorded in 2017, corresponding to the rate of 11.3 cases per 100,000 inhabitants.

In 302 (60.8\%) of the 497 cities of RS, there were cases of suicide. The state's capital, Porto Alegre, had the highest number of victims ( $n=120)$, with a rate of 8.1 cases $/ 100,000$ inhabitants. Already the André da Rocha city, had the highest state rate, 153.1/100,000 inhabitants.

In figure 1, it can be observed that Passo Fundo and Caxias do Sul macroregions, had the highest suicide rates, both with 13.9 cases/100,000 inhabitants.

The region with the highest rate in the state (20.8 cases/100,000 inhabitants) was the Vale do Rio Pardo. Figure 1 also shows the rates by city that makes up this region. The highest rate in the region was observed in the Vale Verde city.

Most victims were born and committed suicide in different cities $(57.2 \%)$, but in the same region $(66.3 \%)$ or macroregion (75.5\%). In 63 cases (4.9\%), birth occurred in other states or countries, including South Korea, the United States, Russia, and Germany, among others.

According to table 1 , the ratio between men and women was $4: 1$, with the obtained rates of 19.9 cases/100,000 male and of 4.5 , female.

Parental absence was observed in 76 cases, corresponding to $5.6 \%$ of women and $6.0 \%$ of men.

The average age of the victims was $47.6 \pm 18.3$ years, ranging from 7 to 101 years.

In 2017 in RS, young people (15 to 29 years old) accounted for $18.8 \%(n=241)$ of suicide victims, providing a rate of 9.1 cases/100,000 inhabitants. The elderly (60 years or older), at $26.9 \%(n=345)$, with a rate of 23.6 cases $/ 100,000$ inhabitants of this age group.

Concerning seasonality, winter was the period of the year where there were most cases of suicide (26.1\%), regardless of gender. According to the age group, the elderly committed suicide more in the summer (29.6\%) and young people more in the spring (30.7\%). It was also observed that most suicides occurred on Wednesdays (15.5\%), the morning shift (34.2\%) and the second half of the month (50.2\%).

With respect to way to commit suicide (Table 1), hanging corresponded to $72.3 \%$ of cases, followed by firearm (14.7\%), intoxication (6.1\%) and high fall (2.9\%). In addition to these forms, suicides involving stabbing, drowning, burns, traffic accidents, brain trauma, electroplession and blunt instrument 
were also recorded. It was also observed that only in cases of poisoning there was a higher number of female victims.

Of the cases involving the use of firearms ( $n=189), 69.3 \%$ ( $n=131)$ underwent residuographic examinations to detect the presence of lead, barium and antimony in the hands of the victims ${ }^{16}$, obtaining $65.6 \%$ of positive results $(n=86)$. In 58 cases $(30.7 \%)$, there was no collection of the necessary material to perform this exam.

Although additional information was not available in all cases (Figure 2), it was observed that $34.1 \%$ of women and $20.6 \%$ of men had depression, totalling $23.2 \%$ of victims.

Taking into account the age group (Table 1), the elderly were more frequent victims than young people between occurrences related to depression and warning of the intention to commit suicide. On the other hand, when previous suicide attempts were recorded, young people were more frequent than the elderly.

It is also noted (Figure 2) that there were practically no female suicides related to alcoholism, financial problems, homicide followed by suicide or cases in which the victim was deprived of her freedom.

In only one case (female, 24 years old) was the victim's participation recorded in the internet game called "blue whale", where the person is encouraged to perform selfdestructive actions whose ultimate goal is to end his or her own life ${ }^{17}$.

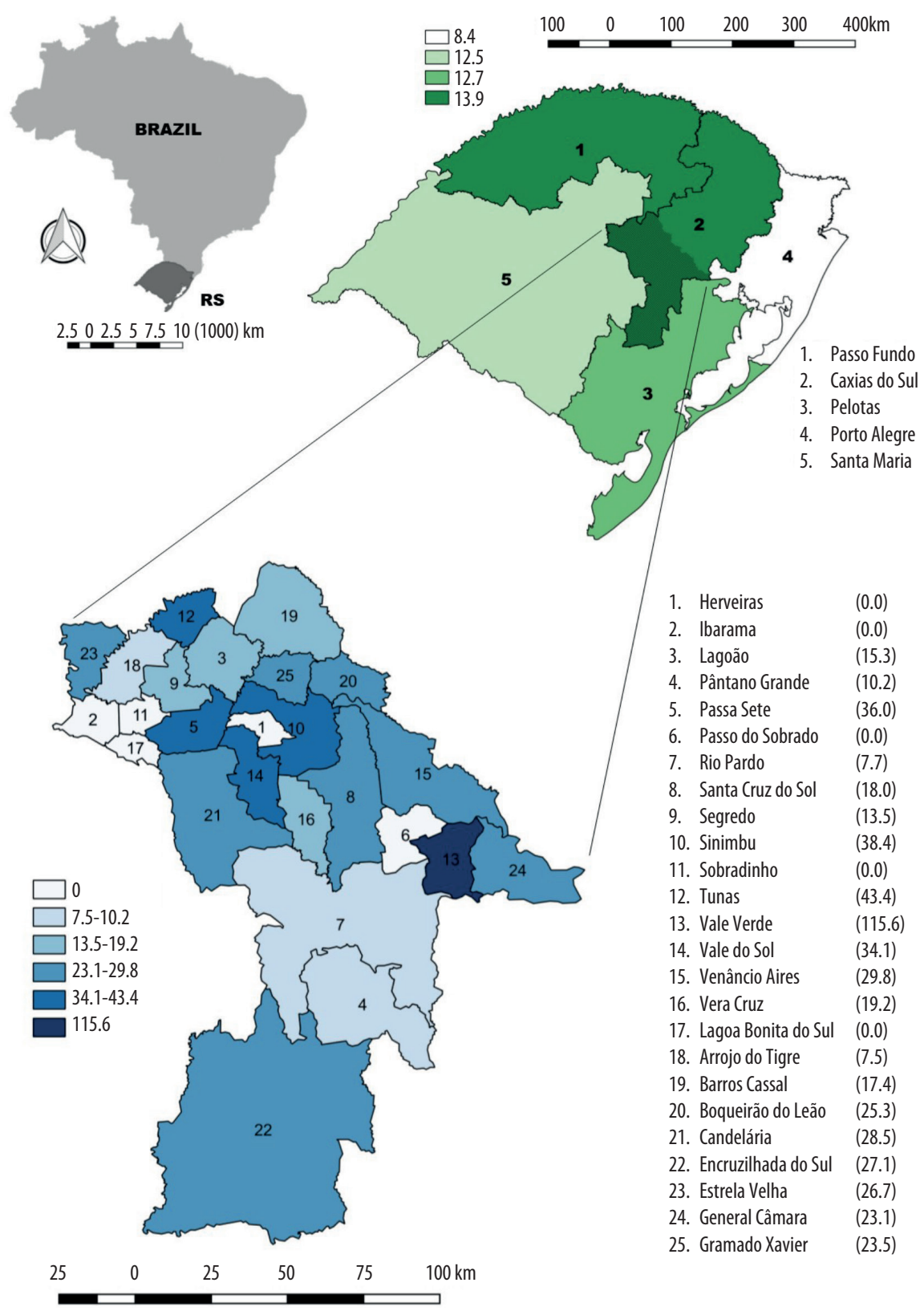

Figure 1. Suicide rates (number of cases/100,000 inhabitants) in 2017 by macroregion ${ }^{14}$ of RS and by city that make up the Vale do Rio Pardo region ${ }^{13}$. Map prepared by LOGE, P.L (2019). 
Table 1. Distribution of suicide victims in Rio Grande do Sul in 2017 by gender and age group, considering parental absence, macroregion ${ }^{14}$, cause of death, positive toxicological results and information on police occurrences

\begin{tabular}{|c|c|c|c|c|c|c|c|c|}
\hline & Men & Women & Children $^{\mathrm{a}}$ & Adolescents $^{b}$ & Adults $^{\mathrm{c}}$ & Elderly $^{d}$ & Young $^{\mathrm{e}}$ & Total \\
\hline Men & - & - & 2 & 47 & 702 & 284 & 198 & 1035 \\
\hline Women & - & - & 1 & 11 & 176 & 61 & 43 & 249 \\
\hline Parental absence & 62 & 14 & 1 & 6 & 43 & 26 & 18 & 76 \\
\hline Porto Alegre ${ }^{14}$ & 313 & 77 & 0 & 18 & 281 & 91 & 86 & 390 \\
\hline Caxias do Sul ${ }^{14}$ & 250 & 56 & 1 & 17 & 211 & 77 & 50 & 306 \\
\hline Passo Fundo ${ }^{14}$ & 197 & 49 & 0 & 11 & 175 & 60 & 43 & 246 \\
\hline Santa Maria ${ }^{14}$ & 157 & 38 & 1 & 6 & 120 & 68 & 31 & 195 \\
\hline Pelotas ${ }^{14}$ & 118 & 29 & 1 & 6 & 91 & 49 & 31 & 147 \\
\hline Hanging & 773 & 168 & 1 & 39 & 667 & 234 & 178 & 941 \\
\hline Firearm & 166 & 23 & 2 & 10 & 105 & 72 & 33 & 189 \\
\hline Intoxication & 37 & 41 & 0 & 5 & 56 & 17 & 13 & 78 \\
\hline High fall & 29 & 8 & 0 & 3 & 24 & 10 & 10 & 37 \\
\hline Stabbing & 16 & 5 & 0 & 0 & 14 & 7 & 3 & 21 \\
\hline Ethanol & 251 & 31 & 0 & 7 & 227 & 48 & 59 & 282 \\
\hline Anxiolytics & 66 & 42 & 0 & 3 & 76 & 29 & 11 & 108 \\
\hline Stimulants & 73 & 9 & 0 & 0 & 82 & 0 & 34 & 82 \\
\hline Antidepressants & 32 & 31 & 0 & 2 & 43 & 18 & 9 & 63 \\
\hline Illicit compounds & 83 & 9 & 0 & 4 & 88 & 0 & 39 & 92 \\
\hline More than one psychotropic & 41 & 35 & 0 & 4 & 61 & 11 & 17 & 76 \\
\hline Ethanol+other psychotropic & 67 & 8 & 0 & 2 & 69 & 4 & 24 & 75 \\
\hline Poisons & 12 & 5 & 0 & 1 & 11 & 5 & 4 & 17 \\
\hline Depression & 213 & 85 & 0 & 9 & 203 & 86 & 42 & 298 \\
\hline Intention statement & 87 & 22 & 0 & 4 & 78 & 27 & 17 & 109 \\
\hline Previous attempts & 64 & 25 & 0 & 3 & 66 & 20 & 24 & 89 \\
\hline Total & 1035 & 249 & 3 & 58 & 878 & 345 & 241 & 1284 \\
\hline
\end{tabular}

${ }^{a}$ 0-12 years old. ${ }^{b} 13-18$ years old. ${ }^{c} 19-59$ years old. ${ }^{d}$ Over 60 years old. ${ }^{e} 15-29$ years old.

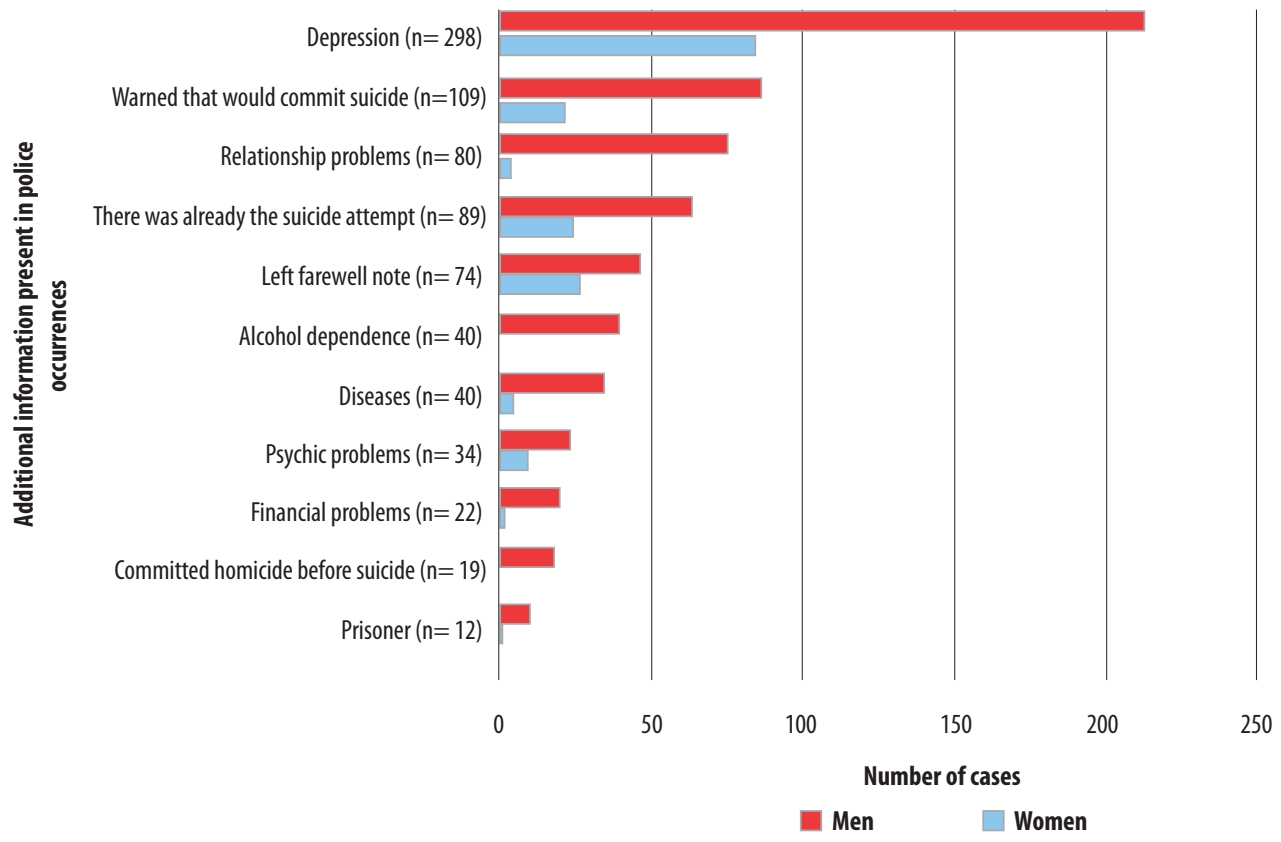

Figure 2. Profile of suicides in Rio Grande do Sul in 2017 by gender, considering the cause attributed and the context of death, according to police occurrences. 
Regarding toxicological assessments, suicide deaths in RS in 2017 required a total of 2,051 expert analysis in biological samples collected from 980 victims, and no laboratory tests were requested in $23.7 \%(n=304)$ of the cases.

The presence of ethanol was detected in $29.9 \%$ ( $n=$ 282) of the samples referred for this analysis $(n=943)$. In 29 cases, the blood alcohol concentration was impaired due to problems of coagulation, leakage or use of expired vial for sample packaging. Mean blood ethanol concentration among men was $14.6 \pm 10.4 \mathrm{dg} / \mathrm{L}(0.5$ to $85.3 \mathrm{dg} / \mathrm{L})$ and among women was $10.4 \pm 8.2 \mathrm{dg} / \mathrm{L}$ ( 0.6 to $36.2 \mathrm{dg} / \mathrm{L}$ ).

About the positive results for alcohol (Table 1), the ratio between men and women was 8:1, with the highest frequency in the Porto Alegre macroregion ( $n=109)$, followed by Passo Fundo $(n=69)$. The prevalence ratio of ethanol positive results among men was 2.5 times higher than among women $(95 \% \mathrm{Cl} 1.6-3.8)$, regardless of macroregion $(p=3.38)$ or age $(p=0.41)$.

Detection of other psychotropic substances was observed in $31.2 \%(n=268)$ of the samples analyzed for this purpose $(n=858)$. Among the positive results, the ratio between men and women was 2:1.

According to table 1, the most present class of psychotropic (except ethanol) in the samples was anxiolytics (40.3\%, $n=108)$, in which diazepam, nordazepam and midazolam were the most detected benzodiazepines. Secondly, compounds with stimulating properties were found, corresponding to $30.6 \%$ of the positive results $(n=82)$, where cocaine was the most frequent substance $(n=79)$.

Antidepressants were observed in $23.5 \%(n=63)$ of the positive cases, including fluoxetine $(n=15)$, sertraline $(n=$ 13), amitriptyline $(n=12)$ and citalopram $(n=11)$. When some antidepressant medication was detected, $41.3 \%$ ( $n=$ 26) presented depression, according to police occurrences. However, evaluating the records where depression was reported, in $64.8 \%(n=193)$ of the cases no antidepressant was found and $26.5 \%(n=79)$ of these victims did not have their biological samples collected for laboratory tests.

Detection of anticonvulsants (carbamazepine $\mathrm{n}=$ 14), antipsychotics (chlorpromazine $n=10$ ), anesthetics (lidocaine $n=9$ ), muscle relaxants, analgesics, antiallergics, hypnotics, antihypertensives, erectile dysfunction drugs and bipolarity were also obtained the positive samples.

Considering other illicit compounds ${ }^{18}$, tetrahydrocannabinol (THC) was detected in 21 samples, corresponding to $7.8 \%$ of positive results $(n=268)$ and methylenedioxymethamphetamine (MDMA) to 1.5\% ( $n=4)$. The victims who presented at least one illicit substance $(n=92)$, were young people in $42.4 \%$ of the cases, the male to female ratio was 9:1 and the highest frequency occurred in Porto Alegre macroregion ( $n=45)$, followed by Caxias do Sul $(n=16)$.
In all victims that MDMA was present, at least one other psychotropic drug was detected simultaneously, including ethanol, cocaine, ketamine and/or THC. In only one of the positive cases for MDMA, the means used by the victim was intoxication.

Simultaneous consumption of ethanol and some other psychoactive compound (Table 1) was observed in 29.9\% ( $n$ $=75$ ) of the samples with positive results for any psychotropic substance $(n=251)$, being 8:1 the proportion between men and women and $32.0 \%(n=24)$ involving young people.

Detection of some poison occurred in $14.9 \%(n=17)$ of the samples sent for this purpose $(n=114)$. Considering the positive results (Table 1), the ratio between men and women was 2:1, the highest frequency was found in the Caxias do Sul macroregion ( $n=10)$, followed by Passo Fundo $(n=3)$. The elderly victims corresponded to $29.4 \%$ of the cases and the young to $23.5 \%$. Nitrite ion was detected in $47.1 \%(n=8)$ of the positive results, followed by carbofuran $(n=3)$, fention, acephate, carbon monoxide, butane, paraquat and 2.4 D.

The suicidal form was associated with the presence of psychotropic drugs (Figures 3, 4 and 5), but there was no association between the macroregion and detection of ethanol, regardless of age or gender.

The intoxication, female victims and negative results for ethanol categories were in the same quadrant in figure 4, as well as illicit compounds, parental absence and young. By evaluating the data in figure 5, it was observed that there was an association between gender and cause of death, between gender and the presence of ethanol and between parental absence and age; however, it was not observed between parental absence and illicit drugs.

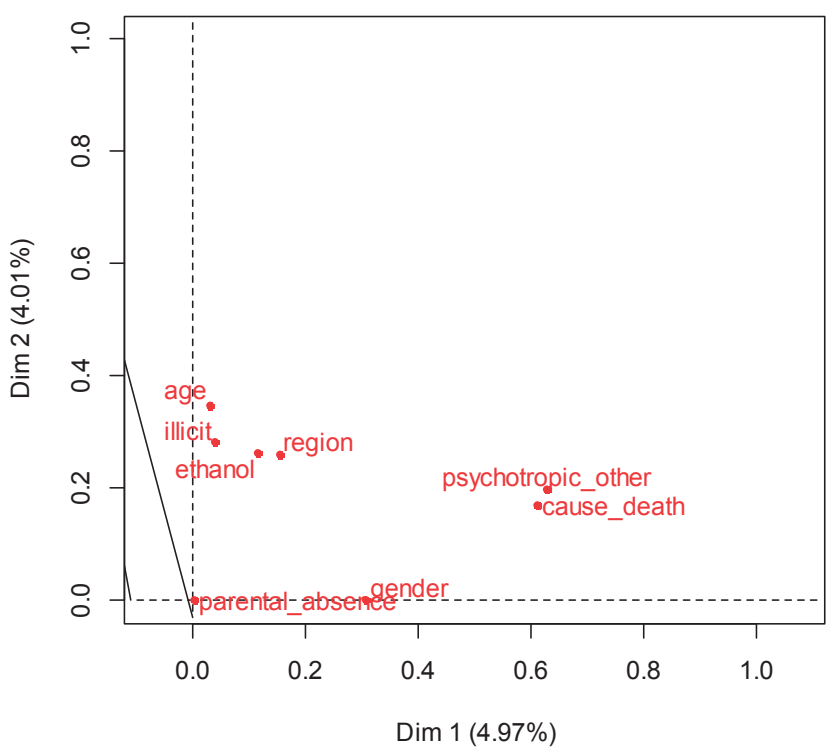

Figure 3. Graphical representation of multiple correspondence analysis between variables related to suicide cases in RS in 2017. 


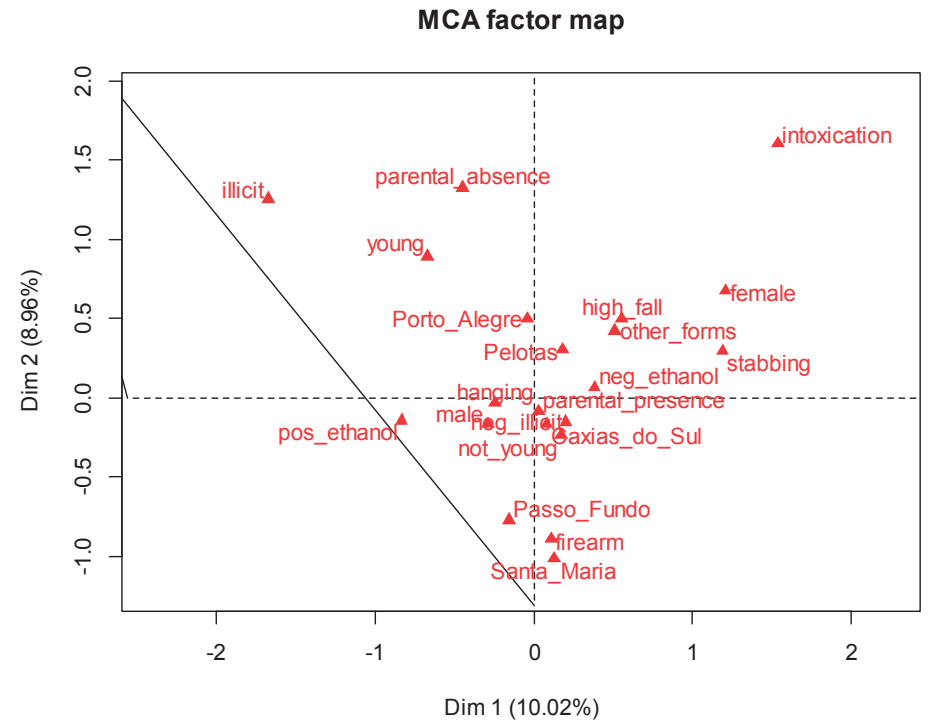

Figure 4. Graphical representation of multiple correspondence analysis between categories of variables related to suicide cases in RS in 2017.

\begin{tabular}{|c|c|c|c|c|c|c|c|}
\hline & Age & $\begin{array}{l}\text { Parental } \\
\text { absence }\end{array}$ & Region & Cause of death & Ethanol & Psychotropic & Illicit \\
\hline \multirow[t]{2}{*}{ Gender } & ${ }^{\mathrm{b}} 0,47$ & $\mathrm{a}, \mathrm{b} 0,40$ & ${ }^{\mathrm{a}} 0,43$ & ${ }^{a} 1 \times 10^{-8}$ & $9 \times 10^{-5}$ & a $7 \times 10^{-12}$ & $a, b 0,02$ \\
\hline & & & & $4 \times 10^{-7}$ & $\mathrm{~b} 4 \times 10^{-4}$ & $2 \times 10^{-10}$ & \\
\hline \multirow[t]{2}{*}{ Age } & & ${ }^{\mathrm{b}} 0,01$ & ${ }^{\circ} 0,76$ & ${ }^{\circ} 0,13$ & $9 \times 10^{-5}$ & ${ }^{\mathrm{b}} 0,57$ & ${ }^{b} 5 \times 10^{-7}$ \\
\hline & & ${ }^{c} 5 \times 10^{-3}$ & & & ${ }^{c} 1 \times 10^{-5}$ & ${ }^{\circ} 0,51$ & $2 \times 10^{-7}$ \\
\hline \multirow[t]{2}{*}{ Parental absence } & & & ${ }^{a} 0,20$ & ${ }^{\mathrm{a}} 0,24$ & ${ }^{\mathrm{a}} 0,87$ & $\mathrm{a}, \mathrm{b} 0,96$ & ${ }^{\mathrm{a} 0} 0,33^{\mathrm{b}} 0,51$ \\
\hline & & & ${ }^{\circ} 0,21$ & $\mathrm{~b}, \mathrm{c} 0,31$ & $\mathrm{~b}, \mathrm{c} 0,92$ & ${ }^{\circ} 0,93$ & ${ }^{\circ} 0,63$ \\
\hline \multirow[t]{2}{*}{ Region } & & & & ${ }^{\mathrm{a}} 0,06$ & ${ }^{\mathrm{a}} 0,34$ & ${ }^{\mathrm{a} 0}, 29$ & ${ }^{a} 0,76$ \\
\hline & & & & ${ }^{\circ} 0,14$ & ${ }^{\circ} 0,26$ & ${ }^{\circ} 0,40$ & ${ }^{\circ} 0,66$ \\
\hline \multirow[t]{2}{*}{ Cause of death } & & & & & ${ }^{\mathrm{a}} 0,07^{\mathrm{b}} 0,08$ & a,b,c $2 \times 10^{-16}$ & ${ }^{\mathrm{a}} 0,52^{\mathrm{b}} 0,16$ \\
\hline & & & & & ${ }^{\circ} 0,13$ & & ${ }^{\circ} 0,23$ \\
\hline \multirow[t]{3}{*}{ Ethanol } & & & & & & $3 \times 10^{-4}$ & $9 \times 10^{-5}$ \\
\hline & & & & & & $8 \times 10^{-4}$ & \\
\hline & & & & & & $3 \times 10^{-3}$ & $\mathrm{~b}, \mathrm{c} 1 \times 10^{-6}$ \\
\hline \multirow[t]{2}{*}{ Psychotropic } & & & & & & & $\mathrm{a}, \mathrm{b} 0,11$ \\
\hline & & & & & & & ${ }^{\circ} 0,18$ \\
\hline
\end{tabular}

Figure 5. $p$ values $(\alpha=0.05)$ obtained by applying the Cochran-Mantel-Haenszel $X^{2}$ test with continuity correction, after adjusting for ${ }^{\mathrm{a}}$ age, ${ }^{\mathrm{b}}$ region or ${ }^{\mathrm{c}}$ gender, to verify the existence of an association between variables related to suicide in RS in 2017.

\section{DISCUSSION}

The number of suicide victims in RS in 2017 increased by $10 \%$ over the previous year, where 1,166 cases were reported, and the rate obtained was almost double the Brazilian rate in $2016^{10}$.

These results may be even higher considering underreporting cases, where suicides are concealed by other types of death, such as traffic accidents, drowning, accidental poisoning, or deaths of undetermined cause ${ }^{8,11}$. The social impact of this problem goes far beyond the actual number of deaths, since it is estimated that for each suicide there are, on average, 5 or 6 people close to the victim who suffer emotional, social and economic consequences ${ }^{1,6,19}$.

One parameter that is used to identify and compare cities regarding the incidence of suicides is the case rate per 100,000 inhabitants. This assessment, however, should consider that in cities with less than 200,000 people, few deaths can substantially increase the mortality coefficient 9 . For example, André da Rocha city, located in the northeast region, registered only 2 cases in a population of 1306 people and Vale Verde city, 4 cases with 3461 inhabitants.

The RSstatehas 22 regions ${ }^{13}$ organized in 5 macroregions ${ }^{14}$. The region of the Vale do Rio Pardo, which had the highest 
state suicide rate, is in the Caxias do Sul macroregion, whose main urban centers are the cities of Santa Cruz do Sul and Venâncio Aires ${ }^{15,20}$, concentrates $4 \%$ of the population state, has a demographic density (2010) of 32.7 inhabitants $/ \mathrm{km}^{2}$ and is where predominantly tobacco is grown. One of the factors that may be related to the incidence of suicides in this region is the prospect of tobacco saturation, which concerns the local economic base, including the level of employment in the industry linked to this segment ${ }^{20}$.

In 2012, the Vale do Rio Pardo region had a socioeconomic development index of 0.725 (middle level) with a gross domestic product of approximately R\$10.8 billion (3.9\% of the total RS). With regard to educational indicators, this region has the sixth lowest value among all other regions, with the lowest enrollment rate in state high school. In addition, the percentage of households with internet access and fixed and mobile telephones is below state averages ${ }^{20}$.

According to WHO data (2000), people who move, mainly from rural to urban areas, or between different regions or countries, are more vulnerable to suicidal behavior'. In RS, in 2017, the data obtained confirmed this feature, except for the rural and urban issue, which was not evaluated.

In 2016, the suicide rates recorded in RS were 17.8 cases/100,000 male inhabitants and 4.5 among women ${ }^{10}$. The results found in this study showed an increase of $11 \%$ among men, while the rate among female victims remained constant. In general, suicide mortality among men is higher 1,10,11,21-23. According to Meneghel (2004), men behave more competitively, impulsively, have more access to firearms and, in some cultures, suffer stress and frustration due to the obligation to perform traditional gender roles, as family economic provider ${ }^{10,11}$. In contrast, women would commit suicide less because they have stronger social protection networks and engage more easily in domestic and community activities, developing a greater sense of connection ${ }^{5,11,19}$. Nevertheless, in Brazil between 1994 and 2004 , the proportional increase in suicide rates was $16.4 \%$ for men and $24.7 \%$ for women ${ }^{6}$.

In relation to suicides in adolescence, must keep in mind that this period of life is characterized by profound changes in physiological, psychological and social order, including the moment when psychoactive drugs consumption begins ${ }^{22}$. Parents and teachers, because they are close, should give young people an opportunity to understand the process they are going through, to encourage them to make decisions and to feel able to deal with their own problems ${ }^{24}$.

Suicide is the second leading cause of death among young people (15-29 years), according to $\mathrm{WHO}^{2}$. This age group represented approximately 1 case per 5 suicides in RS in 2017. Suicide death rates among young individuals have increased in countries such as Australia, Canada, Kuwait, New Zealand, Sri Lanka and the United Kingdom. In Brazil, between 1979 and 1998, there was an increase in these rates in 11 capitals, with the highest values recorded in Porto Alegre and Curitiba ${ }^{25}$.

Although it was not possible to assess the absence of parents throughout the victims' lives, the registration of only one parent on the birth certificate proved to be a risk factor for suicide among young people, confirming other published data ${ }^{6}$.

Considering the chosen way to commit suicide, hanging was the most frequent means among RS victims in the studied period, as already reported in several other states or countries $8,11,21,23,26,27$.

When firearms are used, the combustion of explosives present in the ammunition generates metallic waste, which passes through the holes of the instrument, depositing itself in the hands of the shooter ${ }^{16}$. Approximately $34 \%$ of the residuographic examinations were negative for these metals in the hands of firearm suicide victims. Regardless of the police investigation into the veracity of death by suicide, two factors may be associated with negative results in this type of examination. One of them refers to the fact that these metals are easily removed from the skin and the other takes into account that pistols, when compared to revolvers, release less waste because they are more closed systems ${ }^{16}$. In any case, the collection of these samples should be mandatory in all firearm suicides.

Although the police record of suicides is not standardized, in many cases lacking information regarding the context of death or its possible causes, the data obtained in this study showed that many victims were at risk because they showed signs that they needed help, depression symptoms, reports of intent to commit suicide and even previous suicide attempts. Often, these behaviors are not properly recognized, generating feelings of guilt and indicating the unpreparedness of professionals and family members ${ }^{24}$. According to Botega (2014), when these victims are properly identified, referred to health services, with careful registration and follow-up, including psychosocial interventions, motivational approaches and regular contact (telephone, for example), there may be a decrease in up to 10 times in the number of cases effected ${ }^{8}$.

About toxicological findings, the lack of biological sample collection of approximately $24 \%$ of the victims revealed problems of standardization in the medical-legal conduct, hindering the obtaining of complete data, as well as the exact evaluation of which substances are related to the cases suicide. Even so, the percentage obtained from samples containing ethanol corroborated the data released by WHO (2000), that approximately one third of suicide cases are related to alcohol consumption'.

According to several authors $1,6,8,9,11,19,24,27-30$, alcohol-related or other psychotropic substance-related disorders are the second most common mental illness associated with suicide after the disorders mood (depression and bipolarity) and can 
be found in 25 to $75 \%$ of all cases. Suicidal risk increases if drug use is associated with psychiatric disorders. In addition, about 5 to $10 \%$ of ethanol-dependent people commit suicide, and the ostensive and early use of other substances, often associated with adolescent and youth suicide ${ }^{1,19}$. The ethanol consumption was 4 times more frequent than that of other psychoactive compounds among male victims.

Regarding the detection of antidepressants in the samples, it is known that, regardless of the class used, in the first weeks of treatment, some patients may present an intensification of suicidal ideas ${ }^{6}$. Consumption of selective serotonin reuptake inhibitors such as fluoxetine, sertraline and citalopram may increase the risk of suicide among young people. Some studies associate the increased use of antidepressant drugs by the population with the higher incidence of suicide cases, but it is necessary to assess whether this increase occurred among treated people or not $^{31}$. For a correct assessment of this kind, police records should be standardized, as well as biological sampling should be mandatory in all suicide cases.

Obtaining positive MDMA results in the presence of other psychotropic substances showed similarity to the findings of Fernando et al. (2012), that is, recreational levels of this amphetamine derivative are found in cases of suicide in combination with other drugs, such as ethanol and ketamine. Suicide forms are governed by accessibility and also by understanding the potential lethality of a particular action or substance. The low ingestion rate of MDMA alone as a suicidal form may be due to the rare adverse reactions manifested by its use, leading to a belief that this substance is not toxic enough to reliably cause death. Chronic use of MDMA has been shown to lead to severe depression with suicidal ideation due to serotonergic neurotoxicity ${ }^{32}$.

With regard to poisons, the most frequently detected compound was nitrite. One source of this anion is nitrate reduction (saltpeter or salitre), which are preservative salts used in the food industry to preserve the color of canned meat and sausages, as well as to prevent the spread of botulism-causing bacteria. Nitrite toxicity is attributed to hemoglobin oxidation to methemoglobin, rendering it unable to bind to oxygen ${ }^{33}$. In the Caxias do Sul macroregion, located in the Serra Gaúcha, there are a large number of family agribusinesses of animal products, which may have facilitated victims' access to nitrite.

Assessments of the relationship between multivariate qualitative parameters can be performed by multiple correspondence analysis. This statistical tool allows to graphically analyze possible associations between more than two variables by reducing the dataset's dimensionality ${ }^{34}$. Interpretation is based on the proximity between variables, or categories, in the same region of space; however, the distances between the points do not have a direct relation in this evaluation ${ }^{35}$, which makes it necessary, therefore, the complementary use of other statistical tests, such as the $\mathrm{CMH}$, which verifies the existence of conditional associations between two binary variables in the presence of a third one, categorical.

Finally, suicide is a behavior with multifactorial determinants, the result of a complex psychological, genetic, cultural and socio-environmental interaction ${ }^{11,19,21}$. Therefore, a multidisciplinary approach is needed, combining government efforts and rescuing the potential of existing networks in the family, school and community, according to the circumstances of each location ${ }^{5,24}$.

Sharing data related to suicide, as has happened in the past, with sexually transmitted diseases or cancer, can make prevention more successful ${ }^{36}$. Access to accurate and impartial public information is an inherent right to the condition of life in society and is the duty of the media, as these media promote reflection, dialogue, collective analysis and, potentially, social representations. Discussions about suicide culminated in the development of a handbook for media professionals on how to disseminate this data and reduced the number of suicide events on the Austrian subway between 1986 and 1991, for example. Through these actions, people could have access to the symptoms of mental illness most linked to suicide and a list of places where they could find treatment, also clarifying the consequences and impact that suicide has on both family and community 10,37.

In addition, restricting access to lethal means, including regulation of the trade in pesticides, alcohol, psychotropic drugs and firearms, as well as stimulating safe architecture in public places, could be effective strategies to prevent suicide $1,8,19,30$.

\section{CONCLUSIONS}

Suicide victims in RS in 2017 were mostly male, with 46\% of cases involving young and elderly. The most used means was hanging and the most frequent context was depression. About $30 \%$ of the samples analyzed showed ethanol, a variable that was associated with adult men, as well as the consumption of other psychotropic substances, including illicit drugs. The Vale do Rio Pardo region had the highest case rate in the state. The information obtained in this work supports new research, because knowledge of local reality allows the development of targeted actions, assists health professionals, psychosocial services and education in identifying the most vulnerable individuals, playing a critical role in reducing new cases and in the elaboration of more preventive public policies.

\section{INDIVIDUAL CONTRIBUTIONS}

Maria Cristina Franck - Conception, project, design, data acquisition, analysis, interpretation of results, writing the article, and approval of the version to be published. 
Ângela Malysz Sgaravatti and Anderson Fraga Morales - Data acquisition, interpretation of results, critical revision of the text, and approval of the version to be published.

Daniel Scolmeister, Viviane Fassina, Clarissa Cassini Bettoni, Fernanda Rafaela Jardim and Carla Cafarate Nunes - Analysis, interpretation of results, revision of the text, and approval of the version to be published.

Renata Pereira Limberger - Conception, design, analysis, interpretation of results, revision of the text, and approval of the version to be published.

\section{CONFLICT OF INTERESTS}

The authors declare that there are no conflicts of interest.

\section{ACKNOWLEDGMENTS}

The authors thank Dra. Bianca de Almeida Carvalho (IGP-RS) for supporting and providing conditions for the execution of this work and Dra. Maristela Goldnadel Monteiro (PAHO) for their contributions to the critical review of the text. The authors declare that there was no funding for the development of this research.

\section{REFERENCES}

1. Organização Mundial da Saúde. Prevenção do suicídio: um manual para profissionais da saúde em atenção primária. Genebra: OMS; 2000. Available from: https://www.who.int/ mental_health/prevention/suicide/en/suicideprev_phc_port.pd. Accessed in: Feb 2, 2019.

2. World Health Organization. National suicide prevention strategies: progress, examples and indicators. Geneva: WH0; 2018. Available from: https://apps.who.int/iris/bitstream/hand le/10665/279765/9789241515016-eng.pdf?ud=1. Accessed in: Feb 2, 2019.

3. Organización Panamericana de la Salud. Prevención de la conducta suicida. Washington: OPAS; 2016. Available from: http://iris.paho.org/xmlui/bitstream/hand le/123456789/31167/9789275319192-spa.pdf? sequence=1\&isAllowed=y. Accessed in: Feb 2, 2019.

4. WorldHealthOrganization.Mentalhealthactionplan2013-2020.Geneva:WH0;2013.Available from: https://apps.who.int/iris/bitstream/handle/10665/89966/9789241506021_eng. pdf?sequence=1. Accessed in: Feb 2, 2019

5. World Health Organization. Preventing suicide: a community engagement toolkit. Pilot version 1.0. Geneva: WHO; 2016. Available from: https://apps.who.int/iris/bitstream/ handle/10665/252071/WH0-MSD-MER-16.6-eng.pdf? sequence=1. Accessed in: Feb 2, 2019.

6. Brasil. Ministério da Saúde. Prevenção do suicídio - Manual dirigido a profissionais das equipes de saúde mental. Brasilia; 2006. Available from: https://www.nescon.medicina. ufmg.br/biblioteca/imagem/1241.pdf. Accessed in: Feb 2, 2019.

7. World Health Organization. Brazil: Number of suicide deaths, by age group and sex, 2014 . Geneva: WHO; 2017. Available from: https://www.who.int/mental_health/suicideprevention/country-profiles/BRA.pdf. Accessed in: Feb 2, 2019.

8. Botega NJ. Comportamento suicida: epidemiologia. Psicol USP. 2014;25(3):231-6.

9. Associação Brasileira de Psiquiatria. Manual para a imprensa: boas práticas de comunicação e guia com recomendações para um texto claro e esclarecedor sobre doenças mentais e psiquiatria. Rio de Janeiro: ABP; 2009.
10. Governo do Estado do RS. Centro Estadual de Vigilância em Saúde. Bol Vig Suicídio. 2018;1(1):1-8

11. Meneghel SN, Victora CG, Faria NMX, Carvalho LA, Falk JW. Características epidemiológicas do suicídio no Rio Grande do Sul. Rev Saúde Pública. 2004;38(6):804-10.

12. Brasil. Ministério da Saúde. Secretaria de Vigilância em Saúde. Perfil epidemiológico das tentativas e óbitos por suicídio no Brasil e a rede de atenção à saúde. Bol Epidemiol. 2017;48(30):1-14

13. Governo do Estado do RS. Assembleia Legislativa do RS. Decreto no 40 349, de 11 de outubro de 2000. Estabelece uma divisão territorial como referência para as estruturas administrativas regionais dos órgãos do Poder Executivo. Available from: http://www.al.rs.gov.br/legis/M010/M0100099.ASP?Hid_Tipo=TEXT0\&Hid_ TodasNormas=3517\&hTexto=\&Hid_IDNorma=3517. Accessed in: Dec 20, 2017.

14. Governo do Estado do RS. Assembleia Legislativa do RS. Decreto no 40 623, de 12 de fevereiro de 2001. Estabelece nova divisão territorial para o Instituto-Geral de Perícias. Available from: http://www.al.rs.gov.br/legis/M010/M0100099.ASP?Hid_ Tipo $=$ TEXTO\&Hid_TodasNormas $=2107 \& h T$ Texto $=\& H i d \_I D N o r m a=2107$. Accessed in: Oct 20, 2018.

15. Brasil. Instituto Brasileiro de Geografia e Estatística. Sinopse do Censo Demográfico 2010. Rio Grande do Sul. Available from: https://cidades.ibge.gov.br/comparamun/ compara.php?lang $=\&$ coduf $=43 \&$ idtema $=130 \& \operatorname{codv}=v 01 \&$ search $=$ rio - grande $-\mathrm{do} 0-$ sul\%7Cirai\%7Csintese-das-informacoes-. Accessed in: Feb 2, 2018.

16. Bruni AT, Velho JA, Oliveira MF. Fundamentos de Química Forense. Campinas: Millennium; 2012.

17. Governo do Estado do RS. Secretaria da Saúde orienta sobre prevenção ao Jogo da Baleia Azul. Available from: https://estado.rs.gov.br/secretaria-da-saude-orienta-sobreprevenca0-a0-jogo-da-baleia-azul. Accessed in: Mar 3, 2019.

18. Brasil. Ministério da Saúde. Agência Nacional de Vigilância Sanitária (Anvisa). Resolução - RDC no 300, de 12 de agosto de 2019. Atualização no 67 da Portaria nº 344, de 12 de maio de 1998. Aprova o regulamento técnico sobre substâncias e medicamentos sujeitos a controle especial. Brasilia; 2019. Available from: http://portal.anvisa.gov.br/ documents/33868/3233596/67+-+RDC+N\%C2\%B0+300-2019-D0U.pdf/7c0b3f950393-4404-9740-0b57f1d56a0a. Accessed in: 0ct 20, 2019.

19. Associação Brasileira de Psiquiatria. Comissão de Estudos e Prevenção de Suicídio. Suicídio: informando para prevenir. Brasília: CFM/ABP; 2014.

20. Governo do Estado do RS. Corede. Perfil Socioeconômico Vale do Rio Pardo. 2015. Available from: https://planejamento.rs.gov.br/upload/arquivos/201603/17095302-perfisregionais-2015-vale-do-rio-pardo.pdf. Accessed in: Feb 2, 2019.

21. Faria NMX, Victora CG, Meneghel SN, Carvalho LA, Falk JW. Suicide rates in the State of Rio Grande do Sul, Brazil: association with socioeconomic, cultural, and agricultural factors. Cad Saude Publica. 2006;22(12):2611-21.

22. Bochner R. Perfil das intoxicações em adolescentes no Brasil no período de 1999 a 2001. Cad Saude Publica. 2006;22(3):587-95.

23. Kõlves K, Potts B, Leo D. Ten years of suicide mortality in Australia: socio-economic and psychiatric factors in Queenslad. J Forensic Leg Med. 2015;36:136-43.

24. Teixeira CMFS. A escola como espaço de prevenção ao suicídio de adolescentes - relato de experiência. 2001. Available from: https://www.revistas.ufg.br/interacao/article/ view/1509. Accessed in: Dec 20, 2018.

25. Werlang BSG, Borges VR, Fensterseifer L. Fatores de risco ou proteção para a presença de ideação suicida na adolescência. Interam J Psychol. 2005;39(2):259-66.

26. Oliveira PRM, Kock DB, Oliveira MR, Ramos F, Souza MCSA. Estudo epidemiológico de suicídios no Vale do Itajaí - SC. Saber Humano. 2016;6(8):175-91.

27. Zerbini T, Ponce JC, Sinagawa DM, Cintra RB, Munoz DR, Leyton V. Blood alcohol levels in suicide by hanging cases in the state of São Paulo, Brazil. J Forensic Leg Med. 2012;19:294-6.

28. Lundholm L, Thiblin I, Runeson B, Leifman A, Fugelstad A. Acute influence of alcohol, THC or central stimulants on violent suicide: a Swedish population study. J Forensic Sci. 2014:59(2):436-40.

29. Zupanc T, Agius M, Paska A, Pregelj P. Blood alcohol concentration of suicide victims by partial hanging. J Forensic Leg Med. 2013;20(8):976-9.

30. World Health Organization. Preventing suicide: a global imperative. Geneva: WH0; 2014. Availablefrom:https://apps.who.int/iris/bitstream/handle/10665/131056/9789241564779_ eng.pdf? sequence=1. Accessed in: Feb 2, 2019. 
31. Isacsson G, Ahlner J. Antidepressants and the risk of suicide in young persons - prescription trends and toxicological analyses. Acta Psychiatr Scand. 2014;129(4):296-302.

32. Fernando T, Gilbert JD, Carroll CM, Byard RW. Ecstasy and Suicide. J Forensic Sci. 2012;57(4):1137-9.

33. Iamarino LZ, Oliveira MC, Antunes MM, Oliveira M, Rodrigues R0, Zanin CICB, et al. Nitritos e nitratos em produtos cárneos enlatados e/ou embutidos. Gestão em Foco. 2015;7:246-51.

34. Souza AC, Bastos RR, Vieira MT. Análise de correspondência simples e múltipla para dados amostrais complexos. Available from: http://www.ime.unicamp.br/sinape/sites/default/ files/Artigo\%20Sinape\%20v2.pdf. Accessed in: Dec 20, 2018.
35. SAS/STAT(R) 9.2 User's Guide, Second Edition. Available from: https://support.sas.com/ documentation/cdl/en/statug/63033/HTML/default/viewer.htm\#statug_corresp_ sect026.htm. Accessed in: Feb 2, 2019.

36. Centro de valorização da vida. Falando abertamente sobre suicídio. São Paulo, 2017. Available from: https://www.cvv.org.br/wp-content/uploads/2017/05/FalandoAbertamente-CVV-2017.pdf. Accessed in: Feb 2, 2019.

37. Melgosa J, Borges M. O Poder da Esperança - Segredos do bem-estar emocional. 1a ed. Tatuí: Casa Publicadora Brasileira; 2018. 